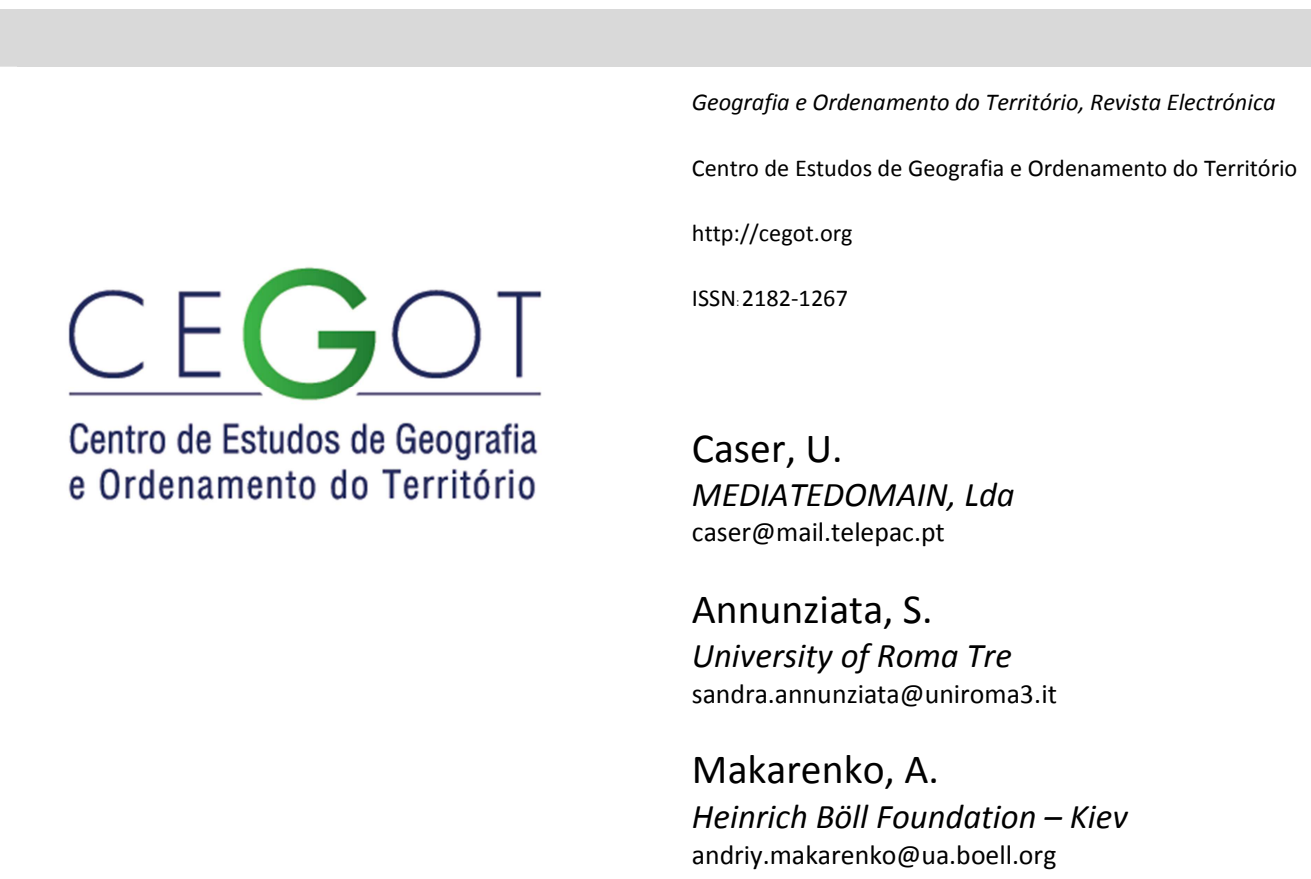

\title{
Collaborative urban design, a promising approach to brownfield recovery - FRUNZE 35, Kiev UA
}

Referência: Caser, U.; Annunziata, S.; Makarenjo, A. (2013). Collaborative urban design, a promising approach to brownfield recovery - FRUNZE 35, Kiev UA. Revista de Geografia e Ordenamento do Território (GOT), n.o 4 (dezembro). Centro de Estudos de Geografia e Ordenamento do Território, p. 7-29

\section{Resumo}

Este artigo descreve um projeto-piloto, excepcionalmente inovador, de desenho e planeamento urbano colaborativo. 16 especialistas (arquitectos, urbanistas, geógrafos e economistas) envolveram-se num processo de construção de consenso profissionalmente desenhado e facilitado, visando o desenvolvimento de uma proposta comum para a reconversão e revitalização de Frunze 35, um sítio industrial abandonado em Kiev (Ucrânia). Após cinco dias de trabalho intenso e baseado numa abordagem multissectorial e multiescala a proposta conjunta abrangeu a história do local, futuras atividades, arquitetura, articulação com os arredores e um modelo de gestão viável. A experiência é transferível para o planeamento urbano em toda a Europa, sempre que o projecto em questão exige uma participação efetiva de actores-chave.

Palavras-Chave: Conversão de Locais Industriais Abandonados - Desenho Urbano Colaborativo - Construção de Consenso - Planeamento Urbano Integrado - Participação Diálogo - Gestão de Conflito - Mediação Ambiental e Socio-Territorial (MAST) 


\begin{abstract}
This paper describes an outstandingly innovative pilot project of collaborative urban design and integrated planning. 16 experts (architects, urbanists, geographers and economists) underwent a professionally designed and facilitated consensus construction process and developed a common project proposal for the reconversion and re-vitalization of Frunze 35, an abandoned industrial site in Kiev (Ukraine). In five days of intense work a multi-sectorial socio-economic and a multi-scale spatial approach led to a project proposal, that focused on history and heritage, activities, architecture, link to the surroundings and a feasible management model for Frunze 35. This experience is transferrable to collaborative urban planning all over Europe, whenever an effective participation and involvement of stakeholders, users and other interested actors are in demand.
\end{abstract}

Keywords: Brownfield Reconversion - Collaborative Urban Design - Consensus Construction - Integrated Urban Planning - Participation - Stakeholder Dialogue - Conflict Management Environmental Mediation

\title{
1. Introduction
}

"If you are young, energetic, have interest in architecture and urban development, and you do care about quality of urban public space, you are invited to participate in a 5-day international workshop "FRUNZE 35 - Rethinking the Industrial Zone" that will take place in Kyiv on May 27-31, 2013." This was the call for an unusual and courageous initiative taken by the Heinrich Böll Foundation, Kiev Department (HBF-K) ${ }^{1}$.

After a traditional architects' competitions promoted in 2012, that ended in great architectural design but without implementation, the idea was to launch a pilot experience: join 16 experts for five days, involve them in a collaborative, dynamic decision making process and have them develop a common proposal to revitalize and hand back to the city and the population of Kiev a derelict industrial site on Frunze Road no 35 .

\footnotetext{
${ }^{1}$ The Heinrich Böll Foundation is part of the German Green political movement that has developed worldwide as a response to the traditional politics of socialism, liberalism, and conservatism. http://www.boell.eu/web/123-380.html
} 


\subsection{The Challenge}

The two first authors of this article were contracted by the third author to lead the workshop. ${ }^{2}$ The overall objective was to design a common proposal for the brownfield Frunze 35 . In this perspective the main challenge consisted in involving all the invited participants ${ }^{3}$ in a structured and intense collaborative and dynamic decision making process to produce a proposal for the rehabilitation of an ex-industrial site. The result should present a feasible vision for the future of Frunze 35 which meets the interests of different future user-groups (residents living nearby, professionals working in the area, women and men, the well-to-do and the poor, the young and the elderly, etc.). The vision should be based on the principles of sustainability, economic viability and - of course - it should be realistic enough to have a real chance of implementation.

\subsection{The Site}

The site, Frunze 35, an abandoned former brewery and malt extract fabric, covers almost 15.000 square meters and is located within a walking distance of Kiev's district Podil, which is a part of the historic center of Ukraine's capital. The area is one of the oldest industrial zones of Kiev and formerly it was - on the one hand - important for the development of Kiev's economic structure and - on the other - a place where innovations in food industry were continuously produced (Heinrich Böll Foundation 2013).

Frunze 35 (Figure 1) belongs to the protected architectural monuments' list of Kiev and was constructed in the mid of the $19^{\text {th }}$ century (Neshevets, et al. 2013).

\footnotetext{
2 Ursula Caser Portuguese-German expert in facilitation of participative processes, from hereon named "the facilitator", Sandra Annunziata, an Italian architect specialized on Integrated Urban Planning from hereon named "Lead Technical Expert" or "LTE, Andriy Makarenko, as a representative of the sponsor Heinrich Böll Foundation Kiev from hereon named: "HBF-K"

${ }^{3} 4$ Ukrainian and 4 non-Ukrainian architects +4 Ukrainian and 4 non-Ukrainian urban planners, geographers and economists
} 

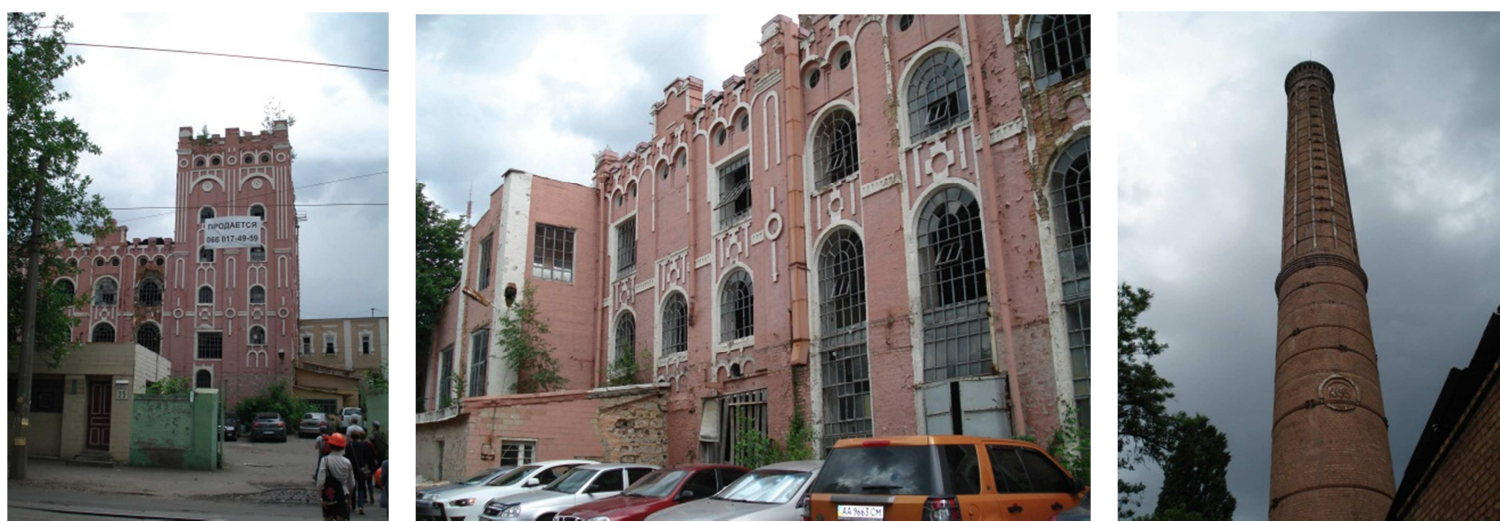

Figure 1: The former brewery and malt extract fabric at Frunze Road 35

The owner of the site, a rich Ukrainian art collector, Igor Voronov, promoted in 2012 the above mentioned closed architectural competition to re-vitalize Frunze 35, targeting the construction of a museum for his collection. Various Ukrainian architectural studios took part in this competition, and the proposal submitted by the Studio Zotov\&Co. ${ }^{4}$ was chosen as best. However, due to financial insecurities and the emerging risks of civil societies' protest, the implementation had to be abandoned and Igor Voronov put the site Frunze 35 on sale.

This "on-sale-situation" suggested a significant level of uncertainty for further use and, at the same time an opportunity to be seized. Therefore Frunze 35 was chosen by Heinrich Böll Foundation Kiev (HBF-K) as a pilot project, fitting well to one of the central objectives that drive the ideas and actions of the Heinrich Böll Foundation: future-oriented urban planning and architecture. The workshop was - at first hand conceived as a didactic simulation - but the organizers never lost hope that - if the outcome was a good and consistent proposal the owner might consider investing in revitalizing the site. The challenge of change was almost real.

${ }^{4}$ The winning proposal came from the studio Zotov\&Co (http://www.zotov.com.ua/uk/project-show/muzei-ihoria-voronova) 


\section{Methodology}

\subsection{General Considerations}

Collaborative Planning is all about meaningful participation of stakeholders in dynamic conversation as sustainability challenges demand innovative approaches towards knowledge production and decision-making. One key aspect is the genuine involvement of interested actors into the design process (Lang et al. 2012), which sometimes creates anxiety by sponsors, as they perceive collaborative processes as "risky" and "potentially provoking confusion and conflict" (Caser, 2009). To meet this challenge effectively, the workshop design was commissioned to an experienced professional facilitator with considerable expertise in the field of conflict management ${ }^{5}$.

The planning process itself, conducted by the Lead Technical Expert (LTE) was rooted in the latest innovations introduced in urban design. The communicative turn in planning (Healy $1996,2007)$ has led to new planning tools and new experiences that seek to overcome the limitation of sectorial approaches in facing complex issues such as urban development (Aalbers \& Beckhoven 2010, Governa \& Saccomani, 2004). Recently competitive cities try to use these new planning instruments, like the Integrated Design Approach to pursue economic, social and spatial goals at a time (Aalbers 2006)

The design approach applied at Frunze 35 is thus based on an eclectic combination of design and planning approaches such as "integrated and strategic planning" and "collaborative urban design". These two terms are used with a specific didactic purpose: Integrated and strategic planning is manly procedural, seeking to reach a consensus and collaboration among different stakeholders and actors involved in the transformation project, providing frames of action as well as risk and benefit analysis. Integrated planning defines the problem in a larger scale, includes the main goals of the project, the competencies that are needed, the actors involved/to be involved in the project and evaluates the financial feasibility of the whole transformation. In one word it "problematizes" the object of study.

\footnotetext{
${ }^{5}$ The author has a 20 years' experience in Portugal in facilitating all kinds of all participative events (Local Agenda 21, Regional and Local Land Management, City Planning, Urban Development, etc.).
} 
The 'integrated' aspects of the strategic approach refer to several levels of integration:

$\rightarrow$ Multisectorial: integrates the action of different sectorial fields; actors are coordinated and their knowledge and competencies interact

$\rightarrow$ Multipurpose: integrates different aspects (social, physical, economic) of the problem resolution and different goals

$\rightarrow$ Multiscale: involves different spatial scales

Besides, there is a specific substantive role played by collaborative urban design: architectural solutions, public spaces' configurations and micro urban changes are defined following a participatory process. Design schemes are able to convey ideas, intents and common sense around a shared vision of transformation.

Both the integrated and collaborative design goals need a clear and well defined "object" (or a problem) around which to discuss the future of a city (Savoldi 2006). This clear object was given: the Frunze 35 site. Its requalification should not simply lead to the rehabilitation and refurbishing of the building but reach out far beyond as it calls for a deeper understanding of deindustrialization phenomena, abandonment and its consequences and advocates for a proposal of innovative heritage re-use as a strategic asset of the city of Kiev. The problem at stake comprises both macro and micro urbanism combining urban planning, economic development, architectural skill, cultural planning and innovative design in order to convey ideas for the future of Kiev. Hence, collective design has to take into account the overall goals and the actors' needs as well as the available budget and possible timeframes (Cremaschi and Annunziata 2011).

In this context, participation becomes a key component of collaborative urban design processes; consequently the Frunze 35 - Workshop design had to foresee the extensive use of communicative and interactive working methods for consensus building (Healy 1992, 2003).

Each participatory process has its own dynamics and procedural demands. So there is no "recipe". Methodology, strategy and process design have to be "tailor made" according to the project's specific contextual characteristics. The crucial point here was to offer a welldesigned but nevertheless flexible process to all participants in order to open arenas where they all together can talk, plan and reach a consensus about the maximum items of discussion. 
Another key characteristic of collaborative design processes, in contrast to the sectorial traditional planning processes is that participants come from diverse cultural backgrounds and bring different competencies and ideas. To mitigate the effects of pre-planning, our participants to Frunze 35 were asked beforehand not to conceive any idea of what the end result could look like. This advice was necessary in order to promote true project oriented engagement from the beginning and offer an arena for a joint definition of a common vision for the site, making the most of all the participants' competencies. All participants stayed for the whole five workshop-days in the same hotel, living eating and working together.

\subsection{The Methodological Approach}

Following a transdisciplinary approach (Klein, 2004; Höchtl, 2006; Brand et al. 2013) and a consensus building philosophy (Zilleßen, 1998, Kersting, 2008; Faget, 2010), during the workshop participants were guided through a collaborative process, fully involving everybody at any time. A sequence of different team-building exercises (Tuckmann, 1965), methodological elements and interactive activities in the first two days allowed participants to knit together their different knowledge and ideas. The methodological strategies of the performed activities were carefully designed and adjusted along the process to make the most out of individual and collective expertise and to develop effective group synergies. Both were extremely valuable and played a vital role in the process. The following table (Table 2) presents the methodological approach and the timeline based on the concrete project experience.

As it can easily be seen, the first two days were dedicated to general information collection and exchange, site visits, interviews with stakeholders, team-building activities, collaborative visioning and the creation of a common language. Participants worked alternately in mixed and homogenous actors' groups to avoid early solution generation. Obviously the facilitator's intervention was comparably more intense in the beginning of the process, for a ("reality and satisfaction check") before joint project proposal elaboration started fully. The LTE's process guiding, consequently was becoming increasingly intense during the project proposal elaboration phase when the participants were ready to finalize a coherent and communicative design scheme. ${ }^{6}$

\footnotetext{
${ }^{6}$ Consensus Building Phase:monday - wednesday morning; Design Phase: mid-wednesday - mid-friday.
} 


\begin{tabular}{|c|c|}
\hline \multirow{24}{*}{ 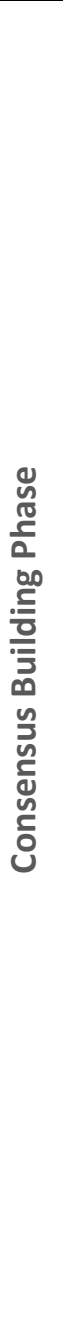 } & Day 1 \\
\hline & Teambuilding Exercise $\rightarrow$ Team-Forming exercise \\
\hline & $\begin{array}{l}\text { Site- and Challenge } \rightarrow \text { Presentations: site/urban planning/collaborative planning } \\
\text { methodology }\end{array}$ \\
\hline & Basic Data + Info $\rightarrow$ Interactive exchange of questions and needed clarification \\
\hline & Presentation $\rightarrow$ Inspiration on design attitudes and preparation of first excursion to the site \\
\hline & A look on Frunze $\mathbf{3 5} \rightarrow$ First excursion to the surrounding area and site visit \\
\hline & Teambuilding Exercise $\rightarrow$ Team-Storming exercise \\
\hline & $\begin{array}{l}\text { World Café } \rightarrow \text { Common language: context, design, management, function orientated } \\
\text { questions }\end{array}$ \\
\hline & The Future Use: Key Challenges - Key Issues $\rightarrow$ Discussion promoting changes of perspective \\
\hline & Day 2 \\
\hline & Teambuilding Exercise $\rightarrow$ Team-Norming exercise \\
\hline & Meeting with stakeholders $\rightarrow$ Interviews with potential users of the site and local experts \\
\hline & Interests and needs of future users $\rightarrow$ Reflection on the interviews \\
\hline & Re-Inventing the site $\rightarrow$ Collaborative distribution of potential activities / functions on-site \\
\hline & What could Frunze 35 be? $\rightarrow$ Construction of an overall consensus of future use of Frunze 35 \\
\hline & Scenarios for Frunze $\mathbf{3 5} \rightarrow$ Functional scenario building on the way to a common proposal \\
\hline & $\begin{array}{l}\text { Scenarios' SWOT } \rightarrow \text { Different scenarios' SWOTs merger }=1 \text { common SWOT for a joint } \\
\text { project }\end{array}$ \\
\hline & What could Frunze $\mathbf{3 5}$ be? Decision $\rightarrow$ Interactive Plenary - Joint Decision Making \\
\hline & Teambuilding Exercise $\rightarrow$ Team-Performing exercise \\
\hline & Day 3 \\
\hline & Reality and Satisfaction check $\rightarrow$ Is everybody happy / can live with the common proposal \\
\hline & Road Map Reflection $\rightarrow$ Definition of a strategy for the development of the project proposal \\
\hline & Distribution of Tasks $\rightarrow$ Review of the agenda in the light of the common proposal (vision) \\
\hline & Another look on Frunze $\mathbf{3 5} \rightarrow$ Second excursion to the surrounding area and site visit \\
\hline \multirow{9}{*}{ 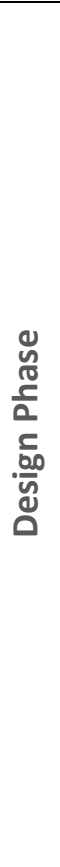 } & New Frunze $35 \rightarrow$ First teams' assignment - Work in Progress \\
\hline & $\begin{array}{l}\text { New Frunze } 35 \rightarrow \text { Project elaboration in changing teams - Work in Progress - Kick off } \\
\text { Hard/soft elements of the transformation / adaptation and flexibility of building re-use, rate } \\
\text { of publicness, quality of public space, time/space frameworks, actorial maps }\end{array}$ \\
\hline & $\begin{array}{l}\text { New Frunze } 35 \rightarrow \text { Project elaboration in changing teams - Work in Progress - General plan } \\
\text { General plan with the surrounding to show the degree of openness with the surrounding } \\
\text { areas, accessibility of Frunze } 35 \text { with the rest of the city (public transport, bike, pedestrian } \\
\text { route), balanced with other centralities and functions }\end{array}$ \\
\hline & Day 4 \\
\hline & $\begin{array}{l}\text { New Frunze } 35 \rightarrow \text { Project elaboration in changing teams - Work in Progress - Detailed plans } \\
\text { "Old and new", function and uses, program of activities and time (week or month agenda } \\
\text { that shows how the new Frunze } 35 \text { will be used over time), actors involved in the use of the } \\
\text { new Frunze 35, management structure proposal, 3D vision, perspectival views of new uses }\end{array}$ \\
\hline & Day 5 \\
\hline & $\begin{array}{l}\text { New Frunze } 35 \rightarrow \text { Project elaboration in changing teams - Finalizing } \\
\text { Elaboration/composition of proposal, final project description, report, presentations }\end{array}$ \\
\hline & New Frunze $\mathbf{3 5} \rightarrow$ Press Conference / Presentation to the Public \\
\hline & Official closing of the workshop $\rightarrow$ Dinner, Party, Final Celebration, Farewell \\
\hline
\end{tabular}

Figure 2: The Methodological Approach 


\subsection{Main Challenges}

The overall idea of this project was to proof that collaborative planning and an integrated approach not only is possible but produces "more realistic" projects of urban transformation. This is particularly important in contexts where such approaches have not been practiced before and where transformations are occurring in a context of "marketoriented" urban development, which means quick processes and little time to reflect. The collaborative approach for Frunze 35 led to the elaboration of a sound prefiguration and imagination of one possible, joint and consensual solution. In the design proposal elements of critical urbanism have been addressed such as reflectivity, (the ability to reflect on the consequences of the planning action) and reliability (the possibility to repeat and implement the same process in different settings.)

As mentioned before, it was clear to everybody that participants are not responding to a real tender. This helped to avoid competition and adversarial strategies from the beginning. Furthermore it was quite obvious that five days would be a very short time for the elaboration of a consensus construction process, which is able to voice the whole plenitude of local interests around the transformation of the site, as well as for the elaboration of a detailed and unified proposal. The LTE even doubted whether it would not be better to elaborate different visions and design schemes that shine a light on the different, somehow conflicting possible trajectories of change for the site. Her argument was that different visions might better simulate a consensus building process and debate about "positive or negative externalities" of the conversion, and that alternative visions/opposing forces would fuel more intensely the engagement of the participants and the debate.

However, the facilitator highlighted that different visions and design schemes do not simulate a consensus building process at all, very on the contrary. Different schemes and visions (as normally used in architectural planning workshops and tenders) are what they are: different, and not collaboratively developed. To promote true participative planning an Iterative Learning Loop (Figure 3) for methodology development and project strategy has to be designed and implemented. The Iterative Learning Loop is part of the concept of adaptive management (Verine, 2008). 


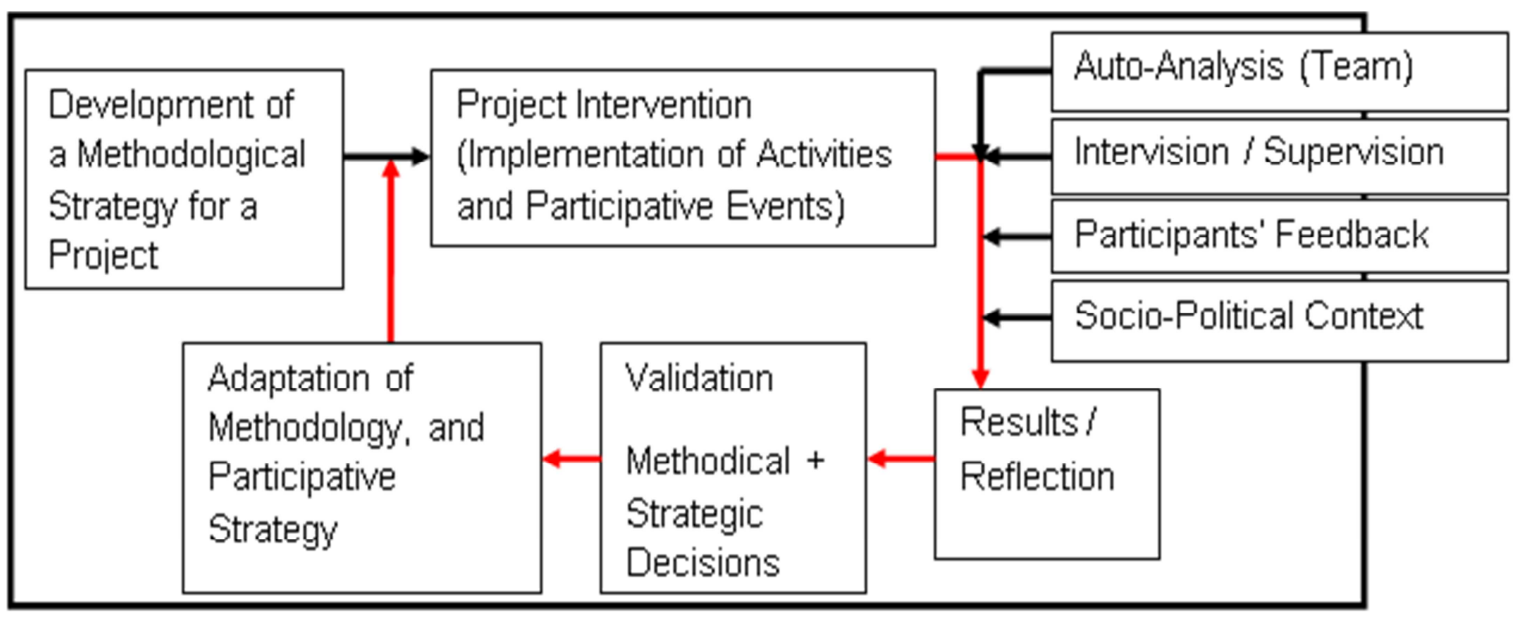

Figure 3: Iterative Learning Loop

The basic idea of Adaptive Management is to use a structured, iterative process to efficiently support decision making in cases of uncertainty. Figure 3 shows how the different inputs (black arrows) contribute to the project development (red arrows).

First step is the development of a preliminary methodological strategy that allows kickingoff the project. Different feed-back mechanisms (auto-analysis of the team-members, interand supervision, participants' feedback and analysis of the dynamic socio-political context) are implemented to gather the information that is needed to improve further management. Reflection on the results, validation and - eventually - adaption of methodological strategic decisions allow the start of the next adaptive management cycle. Adaptive management is therefore not only a project steering strategy but also a learning process (Holling, 2005) and improves management outcomes (Allan \& Stankey 2009).

Even so, there are specific challenges to be met in both the Consensus Building Phase and the Design Phase. Next, three of the most decisive challenges are presented:

\subsubsection{The Challenge of Multidimensional Uncertainty}

As the intention was to promote consensus construction regarding future uses and - based on this vision - one commonly supported, detailed proposal, the demands in terms of time for the different activities within the planning process were not exactly foreseeable. Neither were the concrete abilities of the participants as they were chosen by a public tender and never have met or worked together before. This meant for the preparation that from day 
three on, the detailed timeline definition got less structured and quite open. Hence, in order to create procedural security and trust this must not be told overtly to participants. The facilitator and the LTE, however, have to be aware at any point that there will be a need for flexibility and adaptive methodology management throughout all the process.

Workshop dynamics depend strongly on the participants' personalities and backgrounds and their way to get together.This is typical and unavoidable for collaborative planning processes. Facilitators and LTEs do not know beforehand the different performance of each participant, and cannot determine the detailed timing of consensus construction dynamics. So there is a need to keep the intervention courageously open but maintain procedural control at the same time in order to get a "feeling for the process" during the first days.

Following this approach it is highly recommendable to prepare a diversity of alternative methodological elements ${ }^{7}$ for each time-slot. As the objective was consensus on a single common proposal the "time for design" has to be necessarily reduced, in relation to the "time for consensus building". The Iterative Learning Loop for process design permits this adaptation and facilitators have to be prepared in terms of methodology and necessary material for change and adaptation.

In case of a timely consensus on a joint proposal the applicable working methods will depend a lot on the chosen project. So beforehand neither organizers nor facilitators or LTES do know what and how participants will focus on, what will be the exact contents and what everybody will need in terms of material and - of course - technical coaching. How to proceed in detail has to be decided on the spot by the leading team.

\subsubsection{The Challenge of the "Right Methodological Choices"}

As mentioned above in the first two days the prepared program has to foresee comparably many short slots of alternative common work in different working groups, with changing composition of participants, and each slot has to have a clear working proposal and methodology. It is absolutely necessary to choose formats where the participants educate

\footnotetext{
${ }^{7}$ Methodological elements in collaborative design processes include e. g. presentations, demonstrations, brainstorming, interviews, group works, open space formats, visioning, and all other interventions that help participants to collaborate productively in a structured way. The choice of methodological elements in certain stages of a project depends largely on the information or skill that is being sought, and it may also be influenced by the aptitude and enthusiasm of the participants.
} 
and empower each other in terms of their expertise, ideas, standpoints and arguments. Each participant has to be enabled to perceive the Frunze35 status quo situation and its potentials from all different perspectives that are possible in this diverse participants' group and all together have to create their "common language".

The adequacy of the methodological elements to be used is paramount. Methodologies in the FRUNZE 35 workshop included activities like general information collection and exchange, site visits, interviews with users and stakeholders, team-building activities, brainstorming, interactive SWOT analysis, collaborative visioning, etc. It is beyond the scope of this paper to describe the selection of methodologies for consensus construction in a comprehensive way. For further readings see e. g. Susskind 1999, Sanoff 1999, Cross 2006, Wates 1999 or Creighton 2005.

Crucial for the design phase in this respect was the need to balance design skills and technical competencies with knowledge coming from cultural planning, urban geography, history and economy, to guarantee that in the final proposal all the participant feel part of a common work.

\subsubsection{The Challenge of "Timing and Emotions' Management"}

The proposal for the recovery of Frunze 35 was elaborated by a group of 16 international researchers in just five days. So reflection and production occurred in a "creative rush". The timing and emotions' management in the consensus building phase and in the project elaboration phase arose very different specific challenges.

In the Consensus Building Phase, especially in the very beginning, anxiety is high on all sides. The participants do not know what concretely awaits them, and the project team does not know whether all the preparation work was adequate and whether participants will happily join in the foreseen activities. In this tense situation, the leading team has to create a climate of trust and security to allow participants to stop worrying about the process and its timing and concentrate on the contents in each moment of the working phases. In this phase the facilitator has to appear competent and trustworthy while conducting the process in order to help participants feel secure. So this phase - if going well - is characterized by high trust of all participants in the competence and capacities of the facilitator. The role of 
the LTE in this phase is strictly supportive. The LTE should not challenge the competence and decisions of the facilitator (surely never in front of the participants) and does not intervene in facilitation at any time. The LTE - in this phase - takes notes on the emerging competencies and knowledge of each participant (e.g. urbanism and design, heritage preservation, economic and cultural planning), and observes the managing approaches of the whole team as a basis for an adequate coaching during the following design oriented phase.

The Design Phase, focusing on the physical elaboration of the project proposal, is characterized by a need for mutual trust in the competences of the LTE and of the fellow participants. Participants have to rely on each other as working groups and they have to produce their results in constant interactivity, even exchanging elements to allow deep insight in the work of the parallel groups. The objective is to promote constantly detailed mutual contributions. Competitive feelings and an eventual need for "mutual control" have to be "put aside", in order to allow genuine collaboration. This is not easy. Paramount in this phase is a very competent LTE, who steers the design process and coaches the working groups technically well. The group works naturally in different velocities, which might lead to upcoming conflict dynamics. Rising conflict and its potential escalation must be recognized and resolved when it occurs in its initial phases. The facilitator, having a secondary role in this phase, restricts his intervention to eventually needed mediations between participants or working groups. In any situation of this phase the LTE leads the works and the facilitator must not challenge the LTE.

\section{Results}

At the end of the second day, two seemingly opposing visions for Frunze 35 's future development were "on the table": one based on a huge initial investment, promoting a quick economic performance of the site, and the other based on a more slowly growing, organic and socially oriented project. After intense discussion all participants agreed that the two concepts were mergeable. Some significant investment as well as a sound economic performance in the long run of the project would be needed anyway, even in later stages of a soft and social oriented development. Bearing these assumptions in mind the team 
consensualized one common vision and strategy, which was reality-checked in the morning of day three.

The participants all agreed furthermore that the transformation process of FRUNZE 35 should develop in an integrated process that incorporated socio/cultural, economic and architectural goals. As such the project should be based on a self-regenerative approach that would create the condition for future investment without losing the communal and socio/cultural "soul" of the project. A key role would be played by a narrative to be built from the historical relevance of the site.

So the group decided to develop the proposal in stages where each stage will include the results and achievements of the previous ones. This step by step approach, comprised therefore all the material and immaterial assets of the site and led to a " 5 -Vector approach" The vectors were: the heritage, the future narrative constructed by activities to be developed, the architectural proposal, the integration of FRUNZE 35 with its direct surroundings and Kiev in general and, last but not least, a sound and convincing management model for each phase.

All these aspects of the plan are beforehand, however unconsciously, clear to all participants becoming consciously clear during the consensus building process.

For each of the strategic vectors initial working groups were formed to kick off the discussions and the concretization of the project proposal. Figure 4 shows the stages of the step-by-step transformation process.

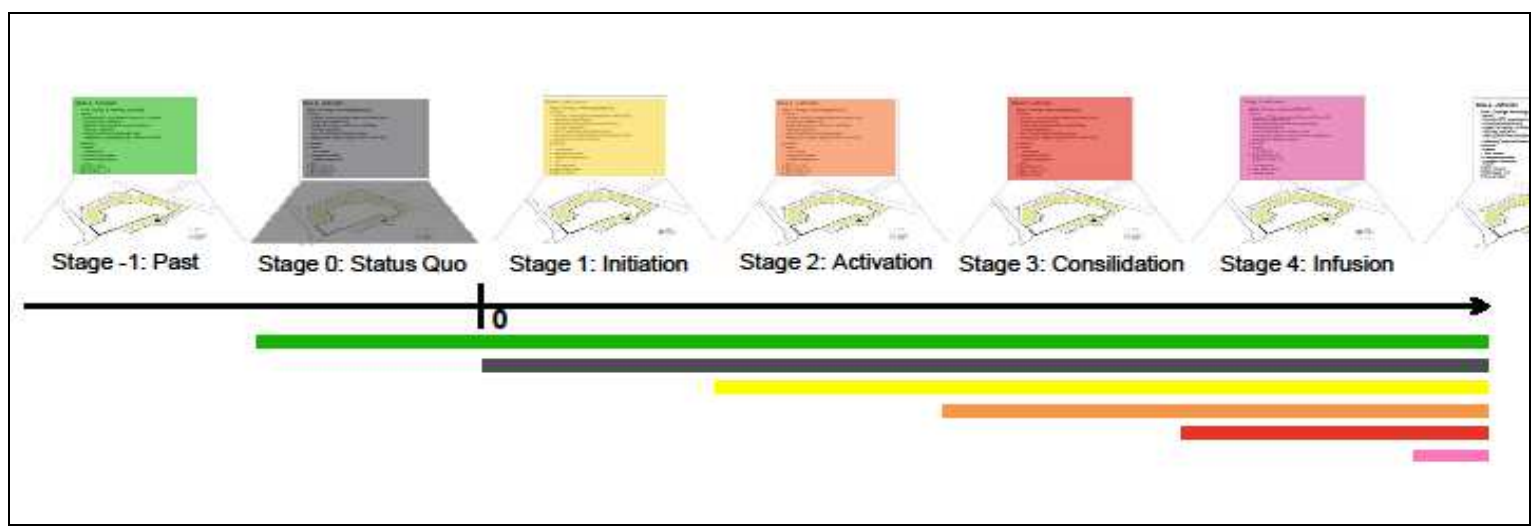

Figure 4: Frunze 35 - The Transformation Process (HEINRICH BÖLL FOUNDATION 2013) 
From day three on, the participants worked in those five working groups organically formed by assuming the ambitions and make the most of the expertise that the participants had expressed and demonstrated during the previous days. The teams were intensely tutored by the LTE that suggested member exchanges when necessary, in order to guarantee a good balance of work load and competencies in each team at any time.

Next we describe the specific challenges and tasks of those five sectorial working groups:

- The task of the "History-and-Heritage" Group consisted in an analysis of the site's heritage, investigating the history of Frunze 35 (historic urban structure, economic development, architectural and technical heritage) and composing a narrative for the past of the site. The group demonstrated that Frunze 35 has been for four centuries a place of continuous innovation (Figure 5). This result led to the title of the final project proposal: Frunze 35 - The Site of Continuing Innovation.

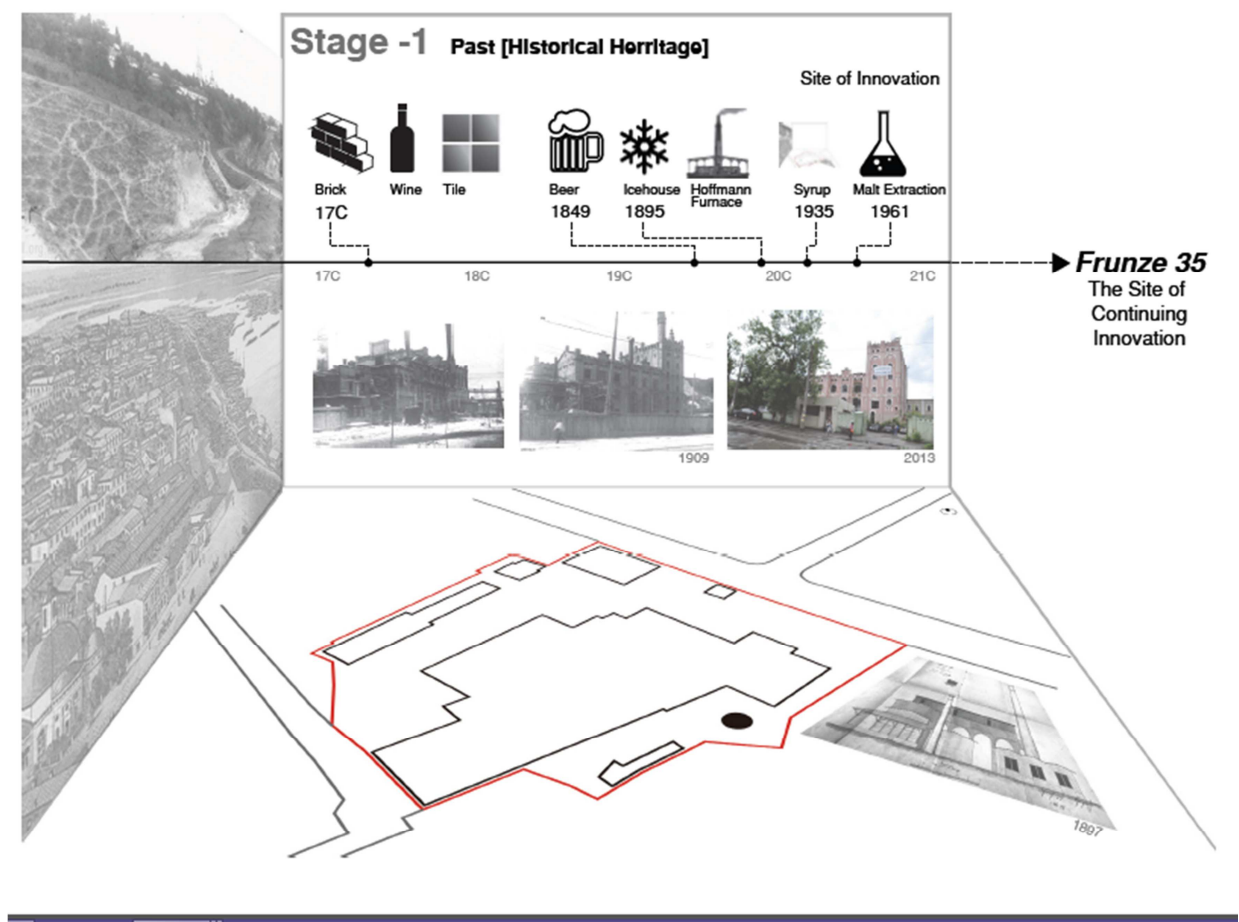

Figure 5: Frunze 35 - Continuing Innovation (Heinrich Böll Foundation 2013)

- The "Activities-to-Happen" Group, responsible for the development of the narrative for the future use, defined concrete goals and gathered activities for each stage of revitalization (divided furthermore in: night/day, winter/summer, regular/sporadic). The group also defined the criteria for space allocation as well as the duties and 
responsibilities of the actors that would be involved in each stage. The activities' scheme fosters that Frunze 35 will evolve smoothly and "organically" from initiation towards consolidation stages. Once achieved the infusion stage the group suggested seeking and maintaining a constant monitoring of the quality of all the activities on site.

- The "Architects"” Group demonstrated the possibility of the buildings to be used in a flexible manner and to be restored in different phases, according to the activities' plan. They called their result "building acupuncture over stages", meaning a clear stage related indication where to demolish parts of the buildings and where to insist on preservation, following all construction and timeline criteria in strong interaction with the other groups. For an insight in the proposed architectural features in stage 4 (infusion) see Figure 6.

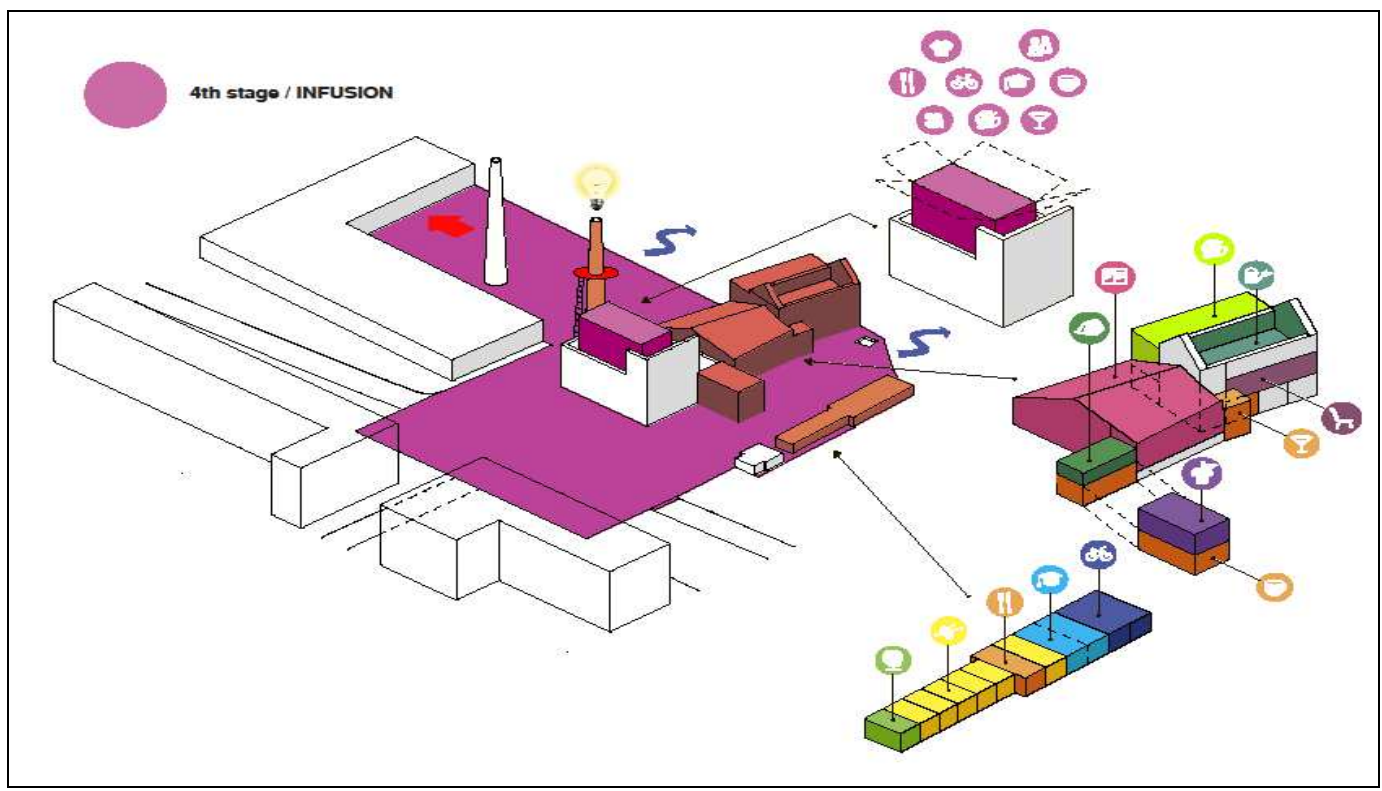

Figure 6: Frunze 35 - Buildings at Stage 4 - Infusion (Heinrich Böll Foundation 2013)

- The "Link-Frunze35-to-the-Surroundings-and-Kiev" Group evaluated the effects of a recovered Frunze35 in each stage on the immediate surroundings and on the city of Kiev as a whole. Specifically focused issues were the existing facilities that appeared 
"usable" for the creation of synergies in a "Necklace Concept", where Frunze 35 would play the role of a focus point, which radiates its effect in both directions of Frunze road (Figure 7). In the "Necklace Concept" Frunze 35 was compared to a medal on a necklace, the pearls of which are the - so far - unused spaces along Frunze road. The basic idea was, that those locations could from the beginning take up social, cultural and commercial functions (Heinrich Böll Foundation 2013, p. 23).

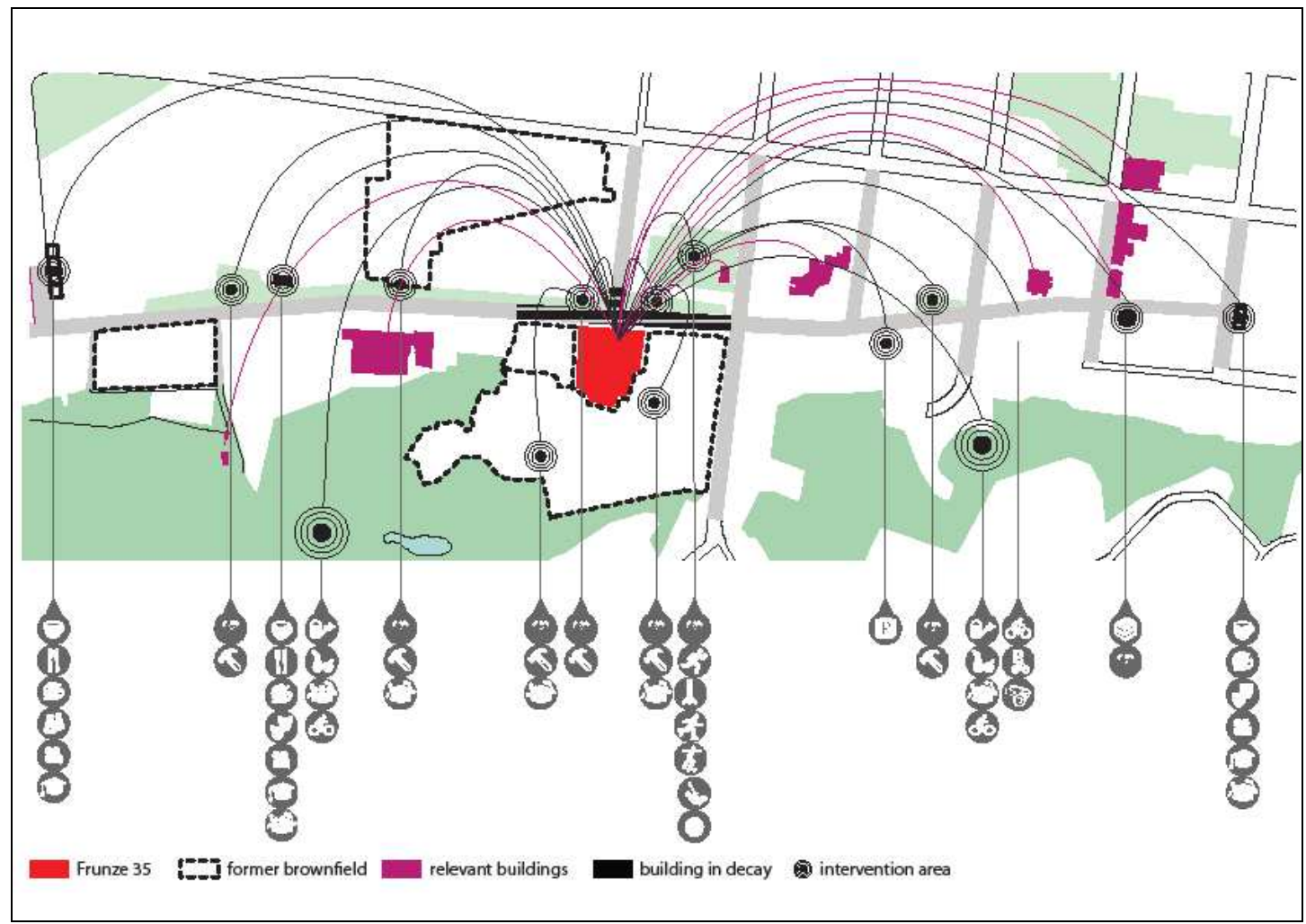

Figure 7: Frunze 35 - Action and Synergies' Map (Heinrich Böll Foundation 2013)

- The "Management Model" Group was in charge to develop management options and an evolving governance model for each of the different stages. In the initiation stage, exploring the viability of the Frunze 35 site, the proposed management model demands the intervention of a pressure group of interested activists to be still created (participants named it "Friends of Frunze 35 - FF35") and potential members should be utterly motivated to participate in the initiative. ${ }^{8}$ The activation stage foresees already a quite consolidated management model, based on the transformation of FF35 into a legal entity that takes responsibility of the further development of the site

\footnotetext{
${ }^{8}$ By the time of the publication of this contribution, the pressure group was already created and is currently implementing the first stage (in order to follow the activities-to-be-developed feel free to join the open Facebook group "Friends of Frunze35" - though mainly in Ukrainian/Russian)
} 
through all the following phases. Potential members of FF35 include the owner, local municipality, NGOs (both European and Ukrainian), philanthropic organizations, and local residents (Figure 8).

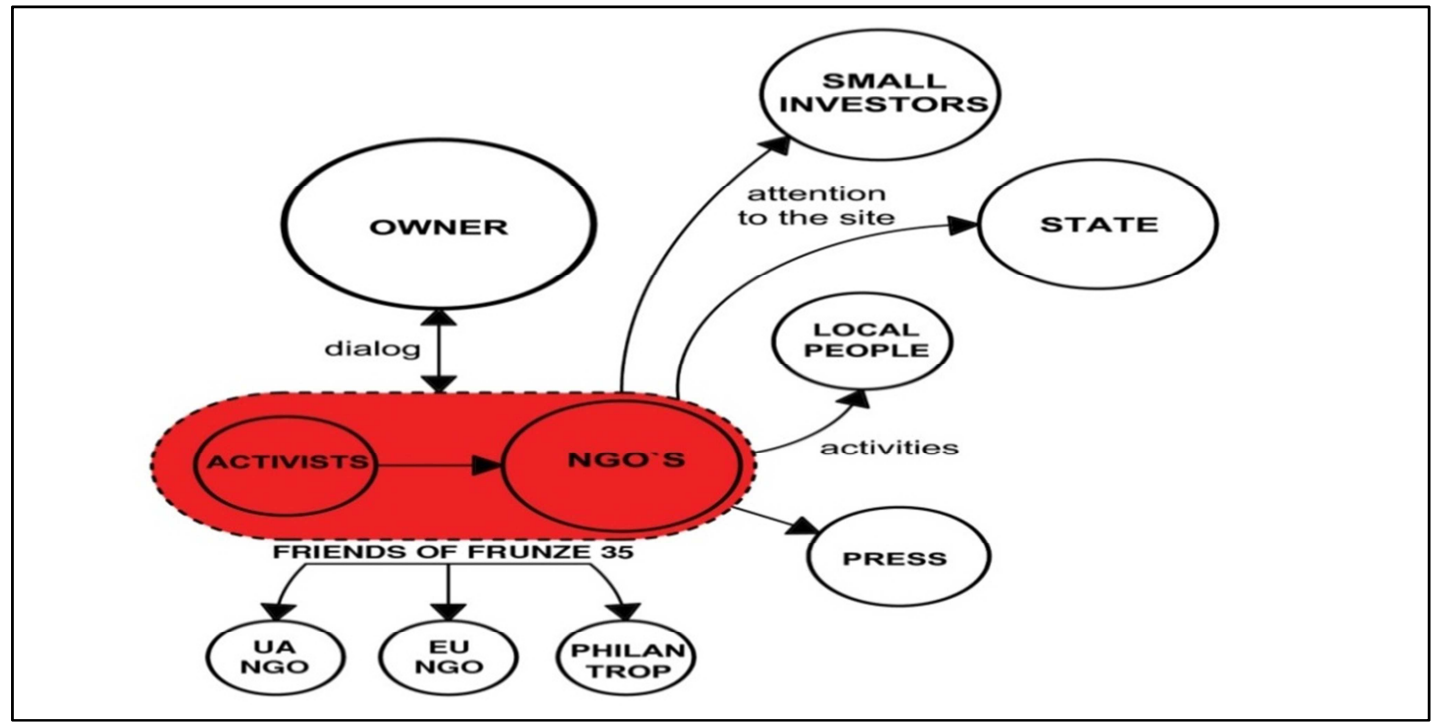

Figure 8: Frunze 35 - Management Model/Activation (Heinrich Böll Foundation 2013)

For the elaboration of the proposal with regard to each of the stages (Past / Status Quo / Initiation / Activation / Consolidation / Infusion) all five working groups constantly interacted and contributed with issues and elements of their expertise (Figure 9).
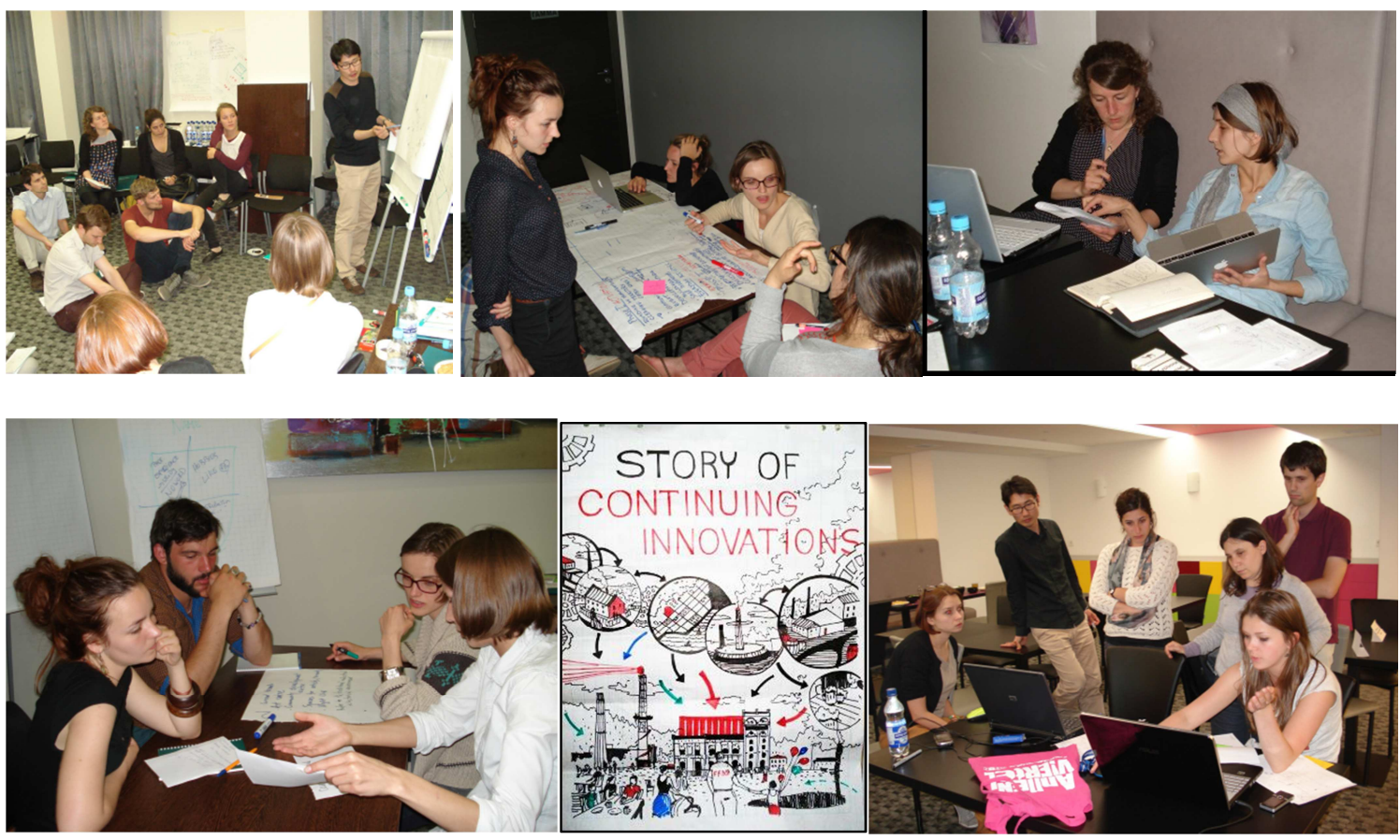

Figure 9: Impressions from the Collaborative Design Sessions 
This workshop permitted the elaboration of a consistent, comprehensive common project proposal that hopefully will prove to be transformational in the evolution of Frunze 35 . This vision of change will be facilitated by an initial supporting group, based on people, on the potential of the space and able to kick-start an ever-expanding process of city-wide improvement (Heinrich Böll Foundation 2013). As such the final result presented a vision of what Frunze-35 could be, fueled by intense collaboration and a genuine belief in the possibility of change.

Presented with the solution, the owner showed interest, and is ready to support the implementation of stage 1, which started concretely in September 2013. At first hand this seems to be a terrific success and now it just remains to be seen what will happen with the project.

\section{Discussion and Conclusions}

Often urban design decisions are promoted based on competition. The most suitable proposal will then be the one considered to be the best by a jury or deciding committee. In fact this also was the case in Kiev before (Heinrich Böll Stiftung 2012).

In our experience we fostered a completely opposite approach. We sought for cooperative dialogue and shared knowledge, avoiding from the beginning competing ideas. As such we involved each participant according to his and her individual expertise in a cooperative work format that allowed them to debate and discuss their ideas. The final proposal demonstrates and is a convincing signal to Ukrainian politicians, planners and civil society, that collaborative and integrated planning is possible.

Involving different experts as well as stakeholders in city planning in a truly and genuine participative and interactive way will guarantee a long lasting and more sustainable urban development, based on endogenous resources, as stakeholders in these processes are not seen as "passive consumers" but actively involved in the planning processes aiming at the negotiation of a set of common objectives and targeting shared responsibilities (CarvalhoRibeiro et al., 2010). In order to integrate the best available knowledge, stakeholders get the 
chance to contribute with their ideas, preferences and aspirations, in order to create ownership for the taken decisions and chosen solutions (Lang et al., 2012). However effective policies to foster genuine stakeholder dialogues are still missing. (Carvalho-Ribeiro et al., 2010, Southern et al. 2011)

Furthermore proof is given that there is nothing to fear about transdisciplinary work, involving different stakeholders in a participative process. Participants in these type of processes are not egoistically thinking only on their own ideas, they are ready to collaborate. One of the success factors, of course is the well-structured process design and the professional facilitation. Collaboration and participation does not mean confusion and adversarial competing ideas, but enthusiastic consensus building processes and joint working on common ideas. The main lesson learnt might be that collaborative and integrated approaches can overcome the limitation, namely the rigidity, of sectorial approaches allowing a more adaptable and flexible (over time and space) program of activities rather than a more and more self-referential type of architectural project.

The shortness of time plus the considerably large group of participants with very different knowledge, ideas standpoints, expertise and cultural backgrounds were a challenge. As the promotion of real interactivity and collaboration was paramount to get everybody enthusiastically involved in a common proposal, there was a decisive need to guide the workshop firm and closely in the beginning (on the two first days) to avoid that participants feel encouraged to think of (own/different/competing) solutions and proposals. Eventually existing "commitments" to own pre-developed ideas by any participant have to be deconstructed right away and substituted by common reflection and discussion, in order to jointly explore the potentialities of the given situation on site.

Professionally facilitated participative processes promote discussion, merging of alternatives and ideas and - in the end - the consensualization of common solutions into win-win outcomes for all participants. However, normally architects and urban planners are competing and not very used to plan collaboratively. Facilitated consensus construction is a new experience, and permits the participants to try out formats and methodologies they never have used before. This might - at first hand - create anxiety but at the end of the day it is perceived and felt as an interesting proposal. 
This kind of process needs adaptive management (see the Iterative Learning Loop - Figure 3). Facilitators and LTE must be genuinely competent and self-confident and - of course work harmoniously together. Furthermore major methodological skills and experience are paramount to promote a fruitful workshop management based on overall collaboration.

However, as written by the participants, "Frunze 35 was not an easy case. The site was abandoned and deteriorated for years. The evolving community of Podil has lost the connection with the place. The economic centers of the city have moved away from this part of the city. A gap emerged between the site and its surroundings and Kiev has lost one of the jewels in its crown." (Heinrich Böll Stiftung 2013, p 3).

But - as the results of the workshop show - Frunze 35 is not lost for Kiev yet. Today there is still a chance to bring it back.

The workshop and its results show impressively how collaborative processes and integrated design permit a time and resource effective joint envisioning of new potentials for cities by different experts (in this case Kiev). The elaboration of a consistent proposal in five days received already considerable recognition in the arena of urban design and urban planning in Ukraine. For the groundbreaking nature of the participants' engagement process it will for sure - receive as well recognition in the international arenas of urban design and urban planning.

And - last but not at all least - in addition to the concrete project proposal for Frunze 35 , the collaborative integrated design which was implemented here, suggests a pattern of transformation that could be reproduced in other ex-industrial sites' recovery in Kiev and elsewhere. In this perspective the experience can count as a pilot project for the consolidation of systematic ex-industrial regeneration approaches in general and elsewhere.

\section{References}

Aalbers M.B, \& Beckhoven V.E. (2010) "The integrated approach in neighborhood renewal: more than just a philosophy?" Tijdschrift voor Economische en Sociale Geografie 101(4): 449-461.

Albrechts, L. (2006). "Bridge the Gap: From Spatial Planning to Strategic Projects". European Planning Studies 14(10): 1487-1500.

Allan, C. \& Stankey, G.H. (2009). Adaptive Environmental Management. CSIRO Publishing \& Collingwood, Australia, $351 \mathrm{p}$. 
Brandt P., Ernst A., Gralla F., Luederitz C ., Lang D., Newig J., Reinert F., Abson D. J. \& Wehrden H. (2013). „A review of transdisciplinary research in sustainability science". Ecological Economics 92: 1-15

Carvalho-Ribeiro, S. M., Lovett, A. \& O'Riordan, T. (2010). “Multifunctional forest management in Northern Portugal: Moving from scenarios to governance for sustainable development". Land Use Policy 27(4): 11111122

Caser, U. (2009). "Socio-Environmental Mediation: Myths and Fears". Revista de Estudos Universitários 35(2): 67-83

Creighton, J. (2005). The Public Participation Handbook: Making Better Decisions Through Citizen Involvement. Jossey-Bass, $288 \mathrm{p}$.

Cremaschi M. \& Annunziata S. (2011). "Strategie vs. strateghi " paper discussed at the conference Abitare I'Italia. Territori, Economie, Diseguaglianze, Società Italiana Degli Urbanisti Torino 2011, proceeding on-line.

Cross, N. (2006). Designerly Ways of Knowing. Springer, 114 p.

Faget, J. (2010). Médiations, les ateliers silencieux de la démocratie. Erès, 300 p.

Governa F. \& Saccomani S. (2004) "From Urban Renewal to Local Development. New Conceptions and Governance Practices in the Italian Peripheries". Planning Theory \& Practice 5(3): 327-348

Healey, P. (2007). “On the Social Nature of Planning". Planning Theory \& Practice 8(2): 133-136.

Healey, P. (2003). "Collaborative Planning in Perspective". Planning Theory 2(2): 101-123.

Healey, P. (1996/2003). The Communicative Turn in Planning Theory and its Implications for Spatial Strategy Formation. Readings in Planning Theory S. Campbell \& S. Fainstein (Eds.). Blackwell, Oxford: 237-259.

Healey, P. (1992). "Planning through debate: the communicative turn in planning theory". Town planning review 63(2): 143.

Heinrich Böll Stiftung (2012): “Третій розділ: Контрактова площа”. Анатомія міста: Київ. Смолоскип: 114157

Heinrich Böll Foundation (2013). Frunze35 - The Site of Continuing Innovation. Final Report of the International Transdiciplinary Workshop in Kiev, Ukraine, 27-31 May 2013, 39 p.

Höchtl, F., Lehringer, S. \& Konald, W. (2006). „Pure theory or useful tool? Experiences with transdisciplinarity in the Piedmont Alps". Environmental Science and Policy 9: 322-329.

Holling, C. S. (2005). Adaptive Environmental Assessment and Management. Blackburn Press, 377p.

Klein, J.T. (2004). “Prospects for transdisciplinarity”. Futures 36(4): 515-526.

Kersting, N. (2008): Politische Beteiligung: Einfhrung in dialogorientierte Instrumente politischer und gesellschaftlicher Partizipation. Verlag für Sozialwissenschaften, $294 \mathrm{p}$.

Lang, D.J., Wiek, A., Bergmann, M., Stauffacher, M., Martens, P., Moll, P., Swilling, M \& Thomas, C .J. (2012) "Transdisciplinary research in sustainability science: practice, principles, and challenges". Sustainability Science 7(1): 24-43.

Neshevets, N, Ilchenko, S \& Fetisiva, A (2013): Frunze 35 - Policy Paper. Master's Study, National University Kyiv Mohyla Academy / Taras Shevchenko National University of Kyiv, 18p.

Sanoff, H. (1999). Community Participation Methods in Design and Planning. Wiley, 1st ed., 320 p.

Savoldi, P (2006) Giochi di partecipazione Giochi di partecipazione. Forme territoriali di azione collettiva, Milano: Franco Angeli. (Game of participation)

Southern, A., Lovett, A., O'Riordan, T. \& Watkinson, A. (2011). "Sustainable landscape governance: Lessons from a catchment based study in whole landscape design". Landscape and Urban Planning 101(2): 179-189

Susskind, L. et al. (1999). The Consensus Building Handbook - A Comprehensive Guide to Reaching Agreement. SAGE Editora, Ltda, 1147 p. 
Tuckman, B. W. (1965). “Developmental sequence in small groups.” Psychological Bulletin 63: 384-399. The article was reprinted in Group Facilitation: A Research and Applications Journal ? Number 3, Spring 2001 and is available as a Word document:

http://dennislearningcenter.osu.edu/references/GROUP\%20DEV\%20ARTICLE.doc.

Verine, L. (2008). "Adaptive Project Management". PM World Today 10(5): 1-9

Wates, N. (1999). The Community Planning Handbook: "How People Can Shape Their Cities, Towns and Villages in Any Part of the World" (Tools for Community Planning). Routledge Ed., 236 p.

Zilleßen, H. (1998). Mediation: Kooperatives Konfliktmanagement in der Umweltpolitik. Verlag für Sozialwissenschaften, $252 \mathrm{p}$. 